\title{
Periacineta mexicana n. sp. (Ciliophora, Suctoria, Discophryida), Epizoic on Mexican Backswimmers of the Genus Buenoa (Insecta, Hemiptera, Notonectidae)
}

\author{
RICARDO MARIÑO-PÉREZ, ${ }^{\mathrm{a}}$ ROSAURA MAYÉN-ESTRADA ${ }^{\mathrm{a}}$ AND IGOR V. DOVGAL ${ }^{\mathrm{b}}$ \\ ${ }^{a}$ Laboratorio de Protozoología, Departamento de Biología Comparada, Facultad de Ciencias, Universidad Nacional Autónoma de México, \\ México, D. F. Mexico, and \\ ${ }^{\mathrm{b}}$ Schmalhausen Institute of Zoology, B. Khmelnitsky str, 15, 01601, Kiev, Ukraine
}

\begin{abstract}
A new species of suctorian in the genus Periacineta, epibiotic on aquatic bugs (Hemiptera, Heteroptera, Nepomorpha), is described on the basis of morphological characteristics of the cell body, lorica, tentacular placement, and stalk, and its 18S rRNA partial sequence gene. Periacineta mexicana $\mathrm{n}$. sp. is a loricate suctorian with elongate body and rounded apical region; tentacles are distributed randomly over apical region and not grouped into fascicles. Macronucleus in adult is elongate and located centrally. The suctorian usually forms closely aggregated pseudocolonies. We provide morphological data based on optical and scanning electron microscopy. A comparison with similar congeners, and emended diagnosis of the genus Periacineta also are provided. The ciliates were found attached to the first two pairs of legs of Mexican notonectids Buenoa pallens and Buenoa spp. (backswimmers).
\end{abstract}

Key Words. Buenoa pallens, ciliate, epibiont, Mexico, notonectid, Periacineta n. sp., suctorian.

S UCTORIANS can be found in all types of aquatic habitats attached to a wide diversity of substrates, including plants and invertebrates, such as crustaceans and insects. For example, Discophrya elongata, attaches to aquatic plants, gastropods, and beetles, and aquatic true bugs, such as the "water scorpions" Nepa cinerea and Ranatra linearis. Periacineta buckei has been recorded from a similar variety of plants and invertebrates, including the arachnid Argyoneta aquatica ("water spider") and nepomorphans (the water scorpions $N$. cinerea and the naucorid Naucoris cimicoides) (Collin 1912; Dovgal 1988, 1991, 1996; Matthes 1954; Matthes, Guhl, and Haider 1988).

Several species of suctorians other than D. elongata and $P$. buck$e i$ are epibionts of aquatic true bugs. Some of them are non-specific in their choice of substrates or hosts. For example, Tokophrya lemnarum has been reported from another type of predatory aquatic hemipteran, $N$. cimicoides (naucorids or "creeping bugs") (Dovgal 1988, 1991), and from the isopod Asellus aquaticus and the crayfish Astacus leptodactylus (Fernandez-Leborans and Tato-Porto 2000). By contrast, Periacineta notonectae has been found only on herbivorous aquatic hemipterans (corixids or "water boatmen"), and Discophrya gessneri which is specific to the naucorid Aphelocheirus aestivalis (Aphelocheiridae) (Matthes et al. 1988).

Species of suctorians comprise $7 \%$ of all ciliates (Dovgal 2002), but few new species have been described recently (Chen, Song, and Hu 2005; Dovgal and Lozowskiy 2008; FernandezLeborans, Zitzler, and Gabilondo 2006). Fifty-two species of suctorian ciliates have been reported from Mexico, mainly as epibionts of phanerogams, algae, and crustaceans (Aladro-Lubel, Mayén-Estrada, and Reyes-Santos 2006; Aladro-Lubel et al. 2007; Mayén-Estrada and Aladro-Lubel 1998).

In the present paper, a new species of Periacineta Collin 1909 is described from the legs of the predatory hemipteran Buenoa (Notonectidae or "backswimmers") collected at two localities in Hidalgo state, Mexico, which represents the first record of epibiotic suctorian for Buenoa species. Morphological information from the new species also enabled us to provide an emended diagnosis of the genus Periacineta.

\section{MATERIALS AND METHODS}

Collection, isolation, and microscopical techniques. The aquatic true bugs were collected with a $0.5 \mathrm{~mm}$ mesh dip net at two sites

Corresponding Author: R. Mayén-Estrada, Ap. Postal 70-374, C.P. 04510, Ciudad Universitaria, México, D.F. México-Telephone number: +(5255) 56224924; FAX number: +(5255) 56224828; e-mail: romaraf@gmail.com in Hidalgo state, Mexico: Tecocomulco Lake $\left(19^{\circ} 52^{\prime} 23^{\prime \prime} \mathrm{N}, 98^{\circ} 23^{\prime}\right.$ $\left.47^{\prime \prime} \mathrm{W}\right)$, and a freshwater pond at Tecomatlán $\left(20^{\circ} 10^{\prime} 60^{\prime \prime} \mathrm{N}\right.$, $99^{\circ} 04^{\prime} 00^{\prime \prime} \mathrm{W}$ ). Five samples were obtained from Tecocomulco, and six samples from Tecomatlán (Table 1). Some hosts were fixed with $70 \%$ ethanol at the sites where they were collected, and others were transported to the laboratory, where they were maintained in aerated aquaria at room temperature. Basibionts were dissected to isolate the leg pairs bearing the ciliates, so that they could be prepared for observation by light and scanning electron microscopy. For light microscopy, body parts of basibionts were fixed in $70 \%$ alcohol, stained with Harris hematoxylin, and mounted in Canada balsam. For scanning electron microscopy (SEM), material was fixed in $1 \%(\mathrm{v} / \mathrm{v})$ glutaraldehyde, transferred to $2.5 \%(\mathrm{v} / \mathrm{v})$ glutaraldehyde in $0.1 \mathrm{M}$ sodium cacodylate buffer ( $\mathrm{pH} 7.2$ ), critical point dried, and coated with carbon and gold.

Morphological characteristics of suctorians were measured, and the maximum, minimum, mean, and standard deviation were calculated for each set of measurements. The distribution of ciliates on areas of basibionts was recorded and the prevalence was calculated following Margolis et al. (1982).

DNA extraction, PCR amplification, and sequencing. Total genomic DNA was isolated from water bugs preserved in $70 \%$ ethanol; tissue was taken from the leg, and DNA was isolated using commercial DNeasy Blood \& Tissue kit (Qiagen). The mitochondrial region cytochrome oxidase 1 (cox-1) was amplified and sequenced. Universal primer sequences used for PCR, corresponded to those designed by Lunt et al. 1996 (UEA7 for-

Table 1. Prevalence of Periacineta mexicana n. sp. on three hosts reported by dates on which samples were taken

\begin{tabular}{lccc}
\hline \hline & $\begin{array}{c}\text { Buenoa sp. 1 } \\
(n=39)\end{array}$ & $\begin{array}{c}\text { Buenoa sp. 2 } \\
(n=199)\end{array}$ & $\begin{array}{c}\text { Buenoa pallens } \\
(n=53)\end{array}$ \\
\hline 2005 February & - & - & $9(17.0)$ \\
March & - & - & $7(13.2)$ \\
April & - & - & $12(22.6)$ \\
May & - & - & $10(18.8)$ \\
July & - & - & $8(15.1)$ \\
August & $3(7.7)$ & $38(19.1)$ & $7(13.3)$ \\
2006 October & $16(41.0)$ & $41(20.6)$ & - \\
2007 March & $14(35.9)$ & $40(20.1)$ & - \\
September & $6(15.4)$ & $40(20.1)$ & - \\
December & 0 & $40(20.1)$ & - \\
2008 March & 0 & - & \\
\hline
\end{tabular}

Data without parentheses are numbers of individual hosts in each sample, and data enclosed in parentheses are percentages of hosts bearing suctorians. 
Table 2. Measurements of Periacineta mexicana n. sp. from two localities

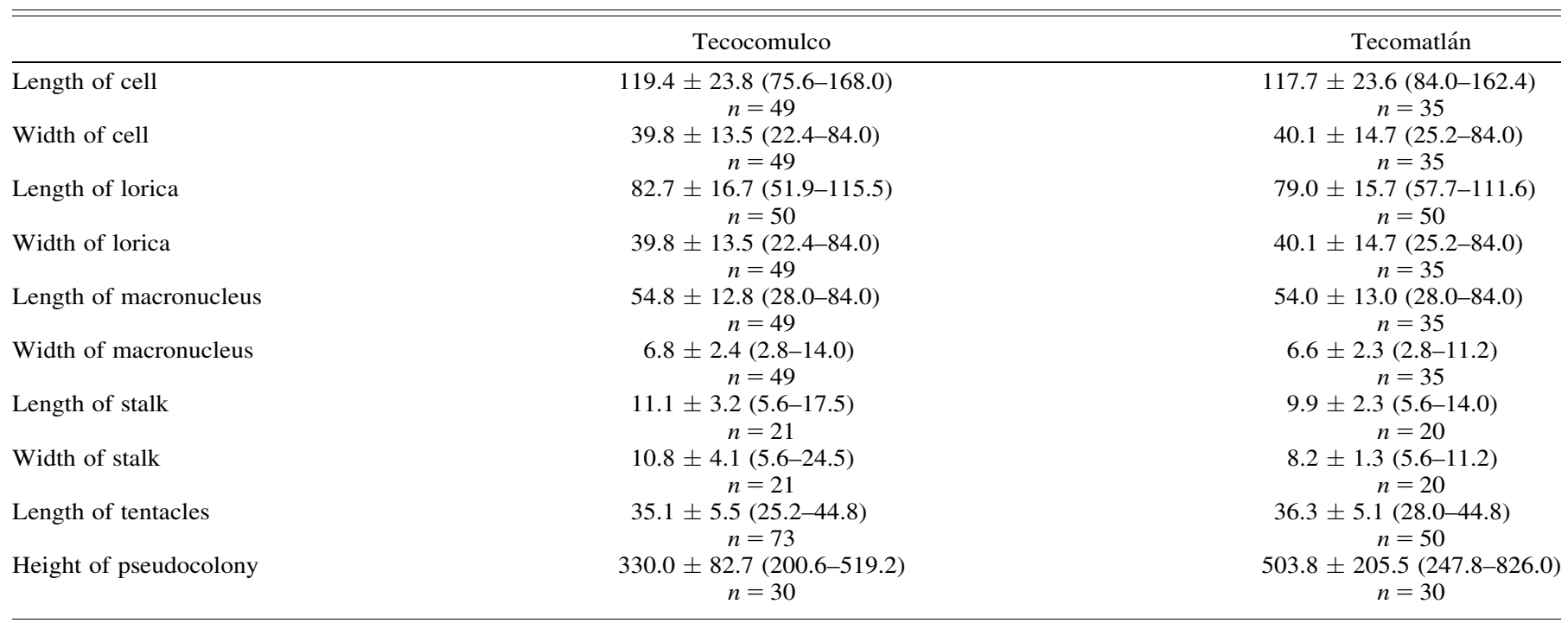

All measurements are in micrometers. For each measurement, the mean and standard deviation are followed by the range in parentheses.

ward, UEA10 reverse). We followed PCR protocols of Schaefer and Renner (2008). For suctorian species, we isolated DNA from pseudocolonies (10-20 cells) detached from aquatic bugs (Buenoa spp.) recollected during January 2010, and fixed in $96 \%$ ethanol. The DNA was extracted following the protocol of Chelex 100 Extraction Procedure for Live Ciliates (D. Lynn, pers. commun.). The PCR amplification of 18S rRNA gene was performed following the procedure described by Puitika et al. 2007, using CS322F and EU929R primers, and using RED Taq (Sigma, Toluca, Mexico).

All PCR products were purified using Centrisep columns. Amplified region were sequenced in both directions using the BigDye Terminator Cycle Sequencing kit (Applied Biosystems Inc., Foster City, CA, USA) in an ABI PRISM 3100 automated DNA sequencer (Applied Biosystems Inc.). The sequences were analyzed with BIOEDIT and submitted to GenBank databases.

\section{RESULTS}

Description (Tables 1-3 and Fig. 1-19). We observed this species as solitary individuals (Fig. 6, 10, 11, 18b-c) and as individuals aggregated into pseudocolonies (Fig. 1-3, 15-17,18e). The lorica fits the cell body closely (Fig. 9-13, 18a), and the rounded, apical part of the cell, usually protrudes beyond the aperture of the lorica, sometimes to half of its length (Fig. 8-9, $12,14-15)$. Tentacles are long, slender, and clavate. They are dis- tributed randomly over the apical region, rather than being in fascicles (Fig. 1-2, 4-5, 7-9, 11); actinophores are absent. The lorica is conical, with the aperture splayed outward and usually slightly curved laterally (Fig. 2, 5, 7, 9-10, 12). Transverse ridges (16-40 in number) are characteristic of the lorica wall (Fig. 2, 10, 16). The stalk is short and broad (Fig. 1-2,10), especially at the base, and is noticeably wide in relation to size of the cell in the youngest individuals (Fig. 6, 18b). With SEM, it can be seen an apical widening of the stalk (physon) (Fig. 6), the upper edge of which overlaps the zone where the stalk joins the lorica.

A single contractile vacuole was observed in the apical region of the cell (Fig. 18a). The macronucleus is located centrally, and is spherical in immature cells (Fig. 11). In mature cells, it is elongate and widened apically, oriented parallel to the long axis of the cell, and two-thirds as long as the cell (Fig. 10, 12-13, 15, 18a). Asexual reproduction is by inversogemmic budding that takes place in the apical zone of the cell (data not shown).

Hyperphoretic pseudocolonies (Fig. 1-3, 15-17, 18e) presumably are formed by swarmers settling on trophonts already attached to the host. This is a characteristic peculiar to this species. Usually, the largest, most basally located individual in the pseudocolony was attached to the surface of the host leg or at the base of a setae, and from two to six secondarily attached individuals were attached laterally or apically to the lorica of this basal individual (Fig. 1-3, 15-16). This results in erect racemose

Table 3. Distribution and prevalence of Periacineta mexicana n. sp. on the appendages of three species of Buenoa

\begin{tabular}{|c|c|c|c|c|c|c|}
\hline & \multicolumn{2}{|c|}{ Buenoa sp. $1(n=39)$} & \multicolumn{2}{|c|}{ Buenoa sp. $2(n=199)$} & \multicolumn{2}{|c|}{ Buenoa pallens $(n=53)$} \\
\hline Anterior femur & $1(2.5)$ & $3(7.7)$ & 29 (14.6) & $13(6.5)$ & $2(3.7)$ & $4(7.6)$ \\
\hline Anterior tarsus & $1(2.5)$ & $5(12.8)$ & $3(1.5)$ & $70(35.1)$ & $1(1.8)$ & $6(11.4)$ \\
\hline Middle femur & $4(10.2)$ & $11(28.2)$ & $27(13.5)$ & 78 (39.2) & $6(11.3)$ & $15(28.3)$ \\
\hline Middle tibia & 0 & $22(56.4)$ & $14(7.0)$ & $106(53.3)$ & $2(3.7)$ & 18 (34.0) \\
\hline
\end{tabular}

Data without parentheses are the numbers of individuals that hosted suctorians; data in parentheses are frequencies of hosts with suctorians attached (\%). 

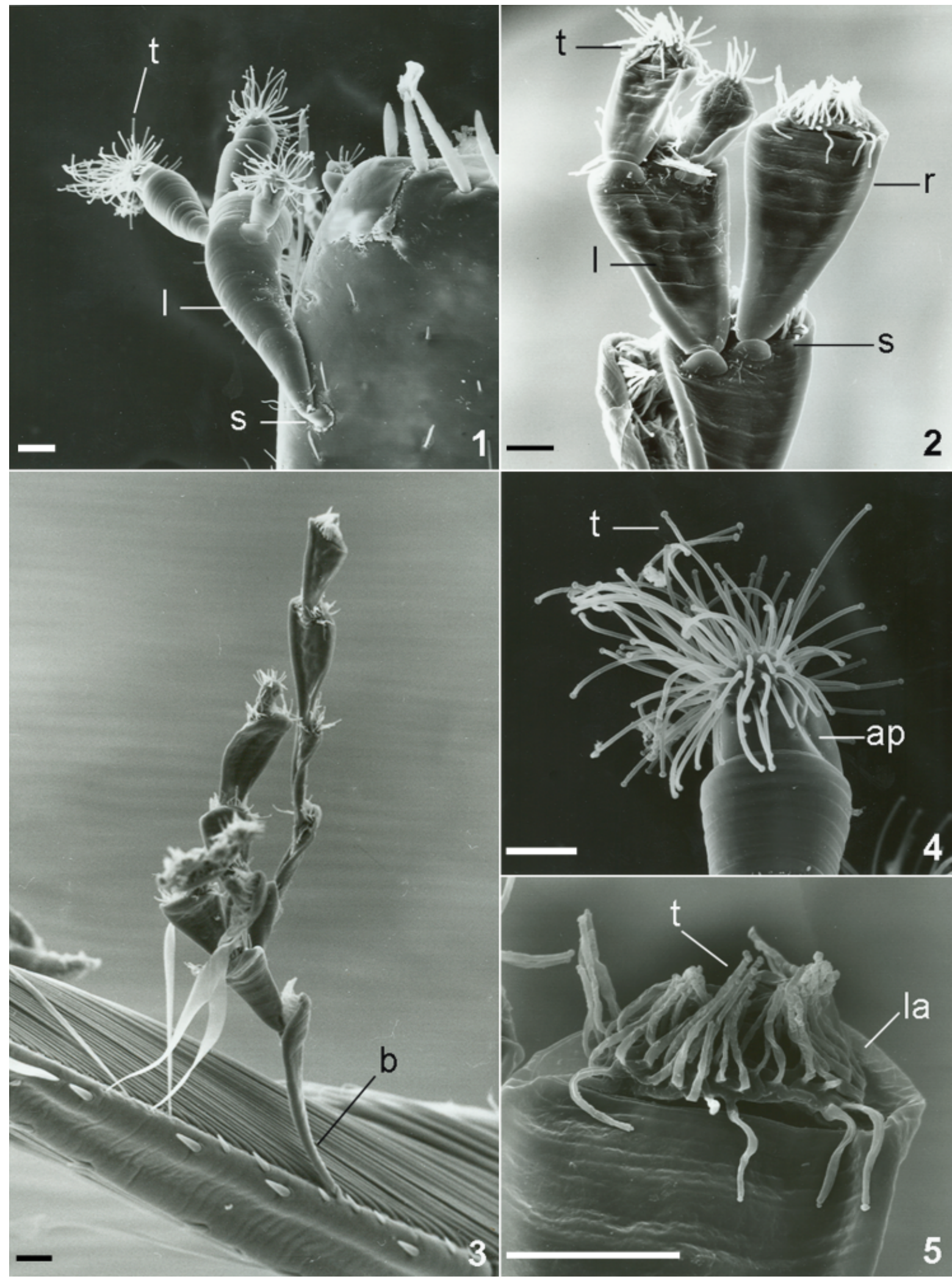

Fig. 1-5. Scanning electron micrographs of Periacineta mexicana n. sp. attached to Buenoa spp. 1-3. Pseudocolonies. 4-5. Detail of individuals. ap, apical part of cell; b, basal individual; 1, lorica; la, lorica aperture; r, ridges; s, stalk; t, tentacles. Scale bars $=24 \mu \mathrm{m}$. 


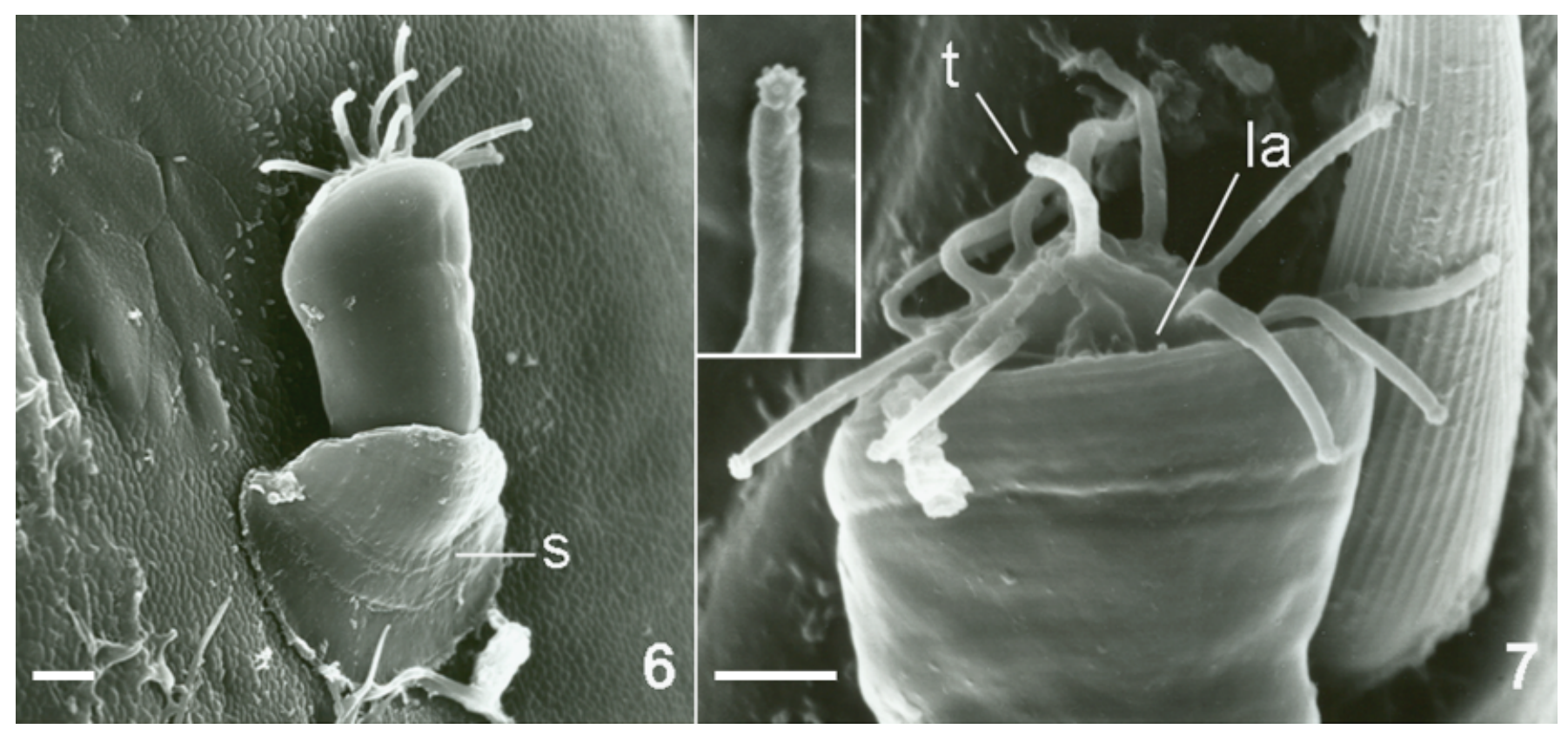

Fig. 6-7. Scanning electron micrographs of Periacineta mexicana n. sp. attached to Buenoa spp. 6. Young individual showing stalk (s). 7. Detail of lorica aperture (la) and tentacles (t). Scale bars $=5 \mu \mathrm{m}$.

pseudocolonies, consisting of up to 32 individuals and measuring $200-826 \mu \mathrm{m}$ in height. An endogemmine suctorian Acineta sp. (Fig. 17) was commonly attached to these pseudocolonies.

Sequences. The GenBank accession numbers of the mitochondrial region cytochrome oxidase 1 (cox-1) partial sequences, of each of the three species of Buenoa are the following: HM357718 (Buenoa sp. 1); HM357719 (Buenoa sp. 2), and HM357720 (Buenoa pallens). For suctorian species Periacineta mexicana n. sp., the accession number of the partial sequence of $507 \mathrm{bp}$ of the $18 \mathrm{~S}$ rRNA gene (43\% GC) is HM357721. The closest sequences in the GenBank database using BLASTN program were the following: $\mathrm{He}$ liophrya erhardi (91\%) (clones 1, 2, 3, 4, and 5; accession numbers: AYY007445.1, AYY007446.1, AYY007447.1, AYY007448.1, AYY007449.1); Prodiscophrya sp. (90\%) (clones 1 and 2, accession numbers: AYY331802.1, AYY331803.1), and Discophrya collini $(90 \%)$ (accession number L26446.1).

\section{DISCUSSION}

Comparison with congeners. Most species of Periacineta have the tentacles grouped in two fascicles, and other than P. mexicana n. sp., only Periacineta hydrochi and Periacineta koeppeli have the tentacles distributed randomly over the apical region of the cell (Table 4). However, the new species differs from $P$. koeppeli, by having a ridged conical lorica instead of a smooth fan-shaped lorica, an ovoid macronucleus located centrally, and a short stalk with a physon. Finally, the new species readily forms pseudocolonies composed of three to six or more individuals; it associates with members of the genus Buenoa (Notonectidae), which is limited to a geographical range extending from southern portions of the Nearctic region in Canada through the United States to the Neotropical region of Mexico, Central America, South America, and the West Indies (Truxal 1953). In comparison, only one other species, Periacineta gyrini, has been reported to form a pseudocolony, and this was a single instance of a pseudocolony that consisted of only two individuals. Moreover, $P$. gyrini differs markedly in morphology from $P$. mexicana by the tentacles arrangement in fascicles, trapeziform shape of lorica, and associates with Gyrinus aeratus, a whirligig beetle that has a strictly Holartic distribution in Canada, Alaska, New York, and European countries. Based on these differences we establish the new species $P$. mexicana n. sp.

Distribution and prevalence on hosts. Periacineta mexicana n. sp. was restricted to the anterior and middle legs of Buenoa sp. 1 and Buenoa sp. 2 (Fig. 19) and B. pallens, and only to the femurs, tibiae, and tarsi of these legs. The frequency of infestation by solitary and pseudocolonial $P$. mexicana combined ranged from $79-85 \%$. The anterior tibia, middle femur, and middle tibia were the segments with the highest overall prevalence of attached suctorians followed by the middle tarsus (Table 3). Pseudocolonies were less frequent on the two species of Buenoa collected from the type locality (35.9\% for Buenoa sp. 1 and $33.6 \%$ for Buenoa sp. 2), compared to B. pallens from Tecomatlán pond, $60.5 \%$ of which harboured pseudocolonies. In all three species of Buenoa the anterior tibia was the segment with the highest frequency of pseudocolonies.

The restricted distribution of suctorians to anterior and middle pairs of legs of Buenoa species could result from two factors: (a) function and architecture of legs, and (b) the degree to which they are exposed to water. The anterior and middle pairs of legs, usually are folded against the body (Fig. 19), are used for feeding functions, and move less vigorously than the posterior pair of legs, which are used for swimming, possess numerous setae, are unfolded, and therefore are more exposed to a more forceful flow of water that could hinder the trophont's ability to capture prey.

According to Dovgal (2002) and Lynn (2008), species of suctorians in the family Periacinetidae, which includes genera Periacineta, Kormosia, Elatodiscophrya, and Peridiscophrya, can be distinguished by the presence of a lorica or stylotheca, a laterally flattened trophont, a ribbon-like or ramified macronucleus, and clavate tentacles arranged in fascicles. However, the tentacles are spread over the apical region of the cell in $P$. koeppeli and $P$. hydrochi, and not in fascicles, which differs from the character state that is considered critical in family diagnosis.

Collin (1909) proposed the new genus Periacineta for those species that lack a stalk and have a lorica like that of Solenophrya 

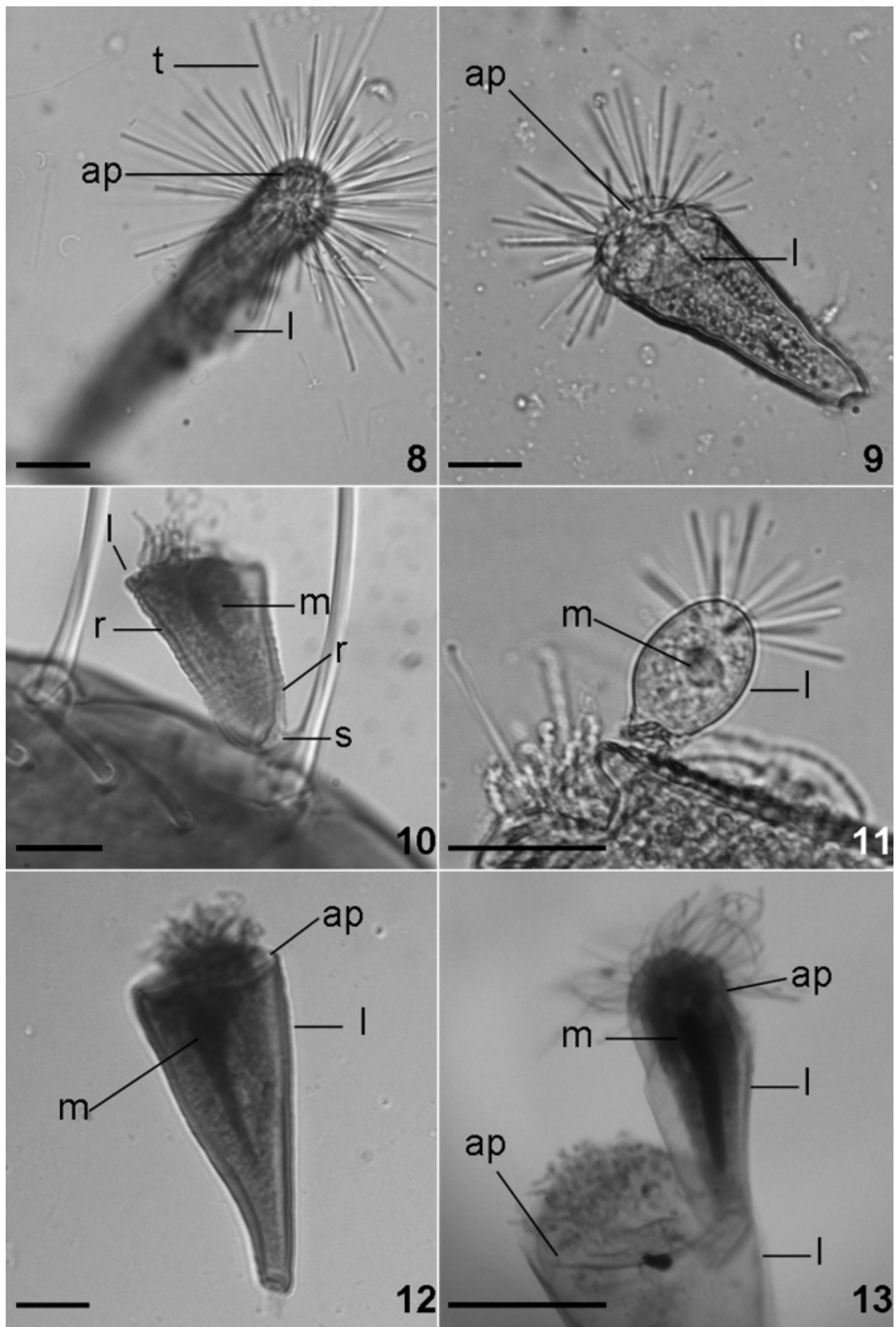

Fig. 8-13. Light photomicrographs of Periacineta mexicana n. sp. attached to Buenoa spp. 8-9, 11. Living individuals. 10, 12, 13. Individuals stained with Harris hematoxilin. 11. Young living individual. ap, apical part of cell; 1 , lorica; m, macronucleus; $r$, ridges; $s$, stalk; t, tentacles. Scale bars $=30 \mu \mathrm{m}$. 


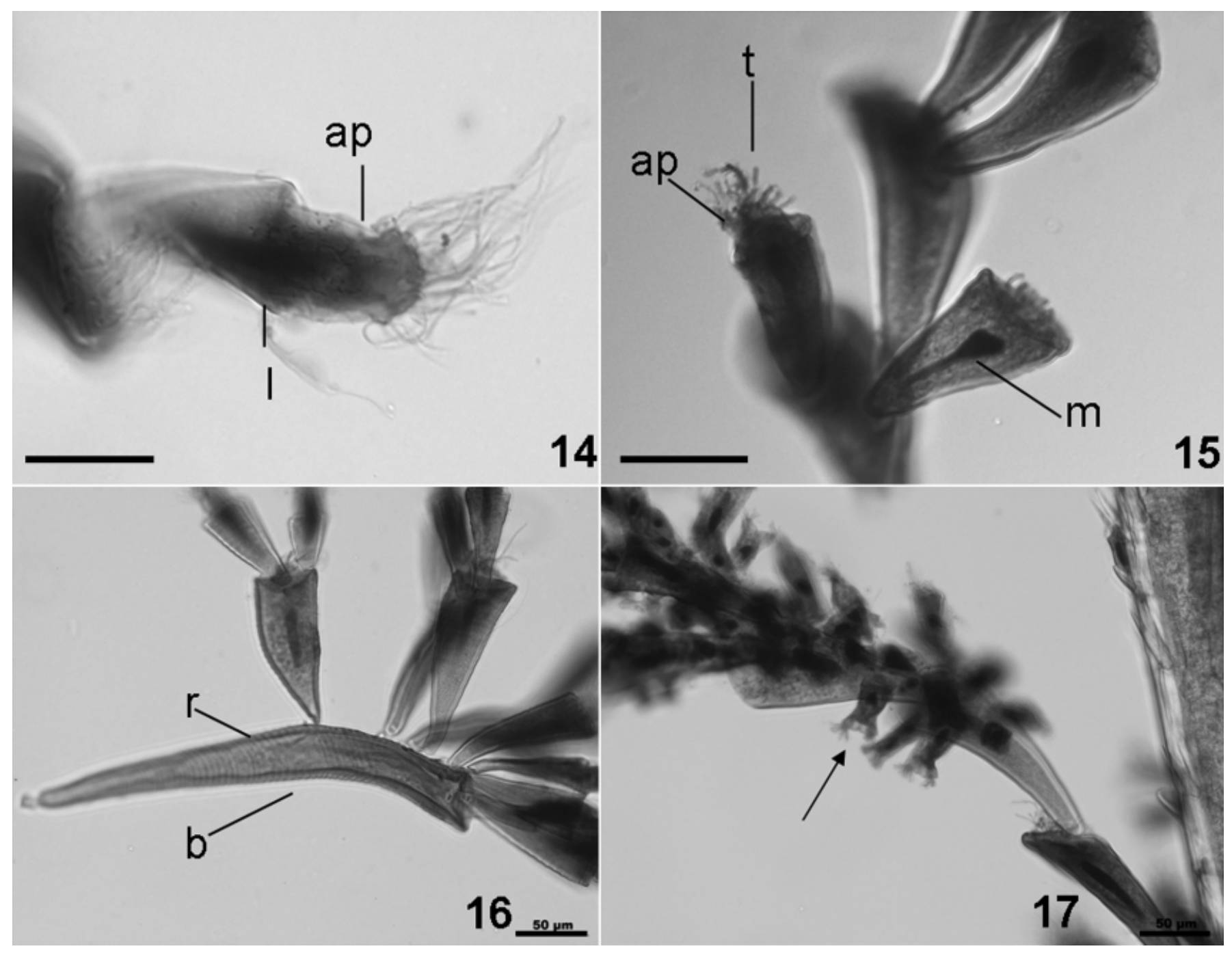

Fig. 14-17. Light photomicrographs of Periacineta mexicana n. sp. attached to Buenoa spp. Individuals stained with Harris hematoxilin. 14. Detail of individual. 15, 16. Pseudocolonies. 17. Pseudocolony showing Acineta sp. (arrow) attached to P. mexicana. ap, apical part of cell; $b$, basal individual; 1 , lorica; $\mathrm{m}$, macronucleus; $\mathrm{r}$, ridges; $\mathrm{t}$, tentacles. Scale bars $=50 \mu \mathrm{m}$.

that attaches to the substrate with the lorica protuberance itself (i.e. thecostyle). Jankowski (1981) evaluated Collin's diagnosis and reported that all species of the genus have a stalk, and concluded that the genus Periacineta must be conserved for the "Acineta-like discophryids." He considered Podophrya buckei Kent, 1880 as the type species of the genus, but did not present a diagnosis of the genus. Jankowski (1981) and Dovgal (2002) included $P$. koeppeli in the genus Periacineta. However, all species of Periacineta except $P$. koeppeli have a stalk for which we transfer $P$. koeppeli to genus Kormosia.

Jankowski $(1981,2007)$ included two subgenera within Periacineta: Fitonacineta Jankowski 1981 for species with a single contractile vacuole and Periacineta Collin 1909 sensu stricto for species with several contractile vacuoles. However, Matthes et al. (1988) reported that the number of contractile vacuoles varies in the type species of Fitoacineta, making this character invalid for taxonomic use in this instance. In any event, establishment of subgenera of protists is generally of no practical use.

Also, Jankowski (1981) proposed three new genera (i.e. Anisarcon, Arcodiscophrya, and Tomodiscophrya) for some species that he removed from Periacineta, but these genera were made junior synonyms of Periacineta by Dovgal (2002). Matthes et al.
(1988) did not include Periacineta in their guide to identification of freshwater suctorians because they place both loricate and aloricate discophryid species into the genus Discophrya Lachmann, and synonymized Periacineta urceolata and Periacineta periacinetoides with Periacineta buckei. Also, the genus Periacineta is considered a junior synonym of Discophrya in the catalogue of generic names of ciliates compiled by Aescht (2001).

Considering the absence of an actual diagnosis of the genus and our description of a new species, we offer an emended diagnosis of the genus Periacineta.

Order Discophryida Jankowski, 1975

Family Periacinetidae Jankowski, 1978

\section{Periacineta Collin 1909 emend}

Emended diagnosis. Loricate discophryid suctorians that attach to the substrate with stalk clearly separated from the bottom of the lorica, instead of a thecostyle. Lorica and cell body laterally flattened or not flattened; shape conical. Lorica smooth or striated. Tentacles clavate, arranged in fascicles or evenly distributed over apical part of cell body. Macronucleus ovoid, elongate or somewhat branched in its apical part. With one or several contractile 


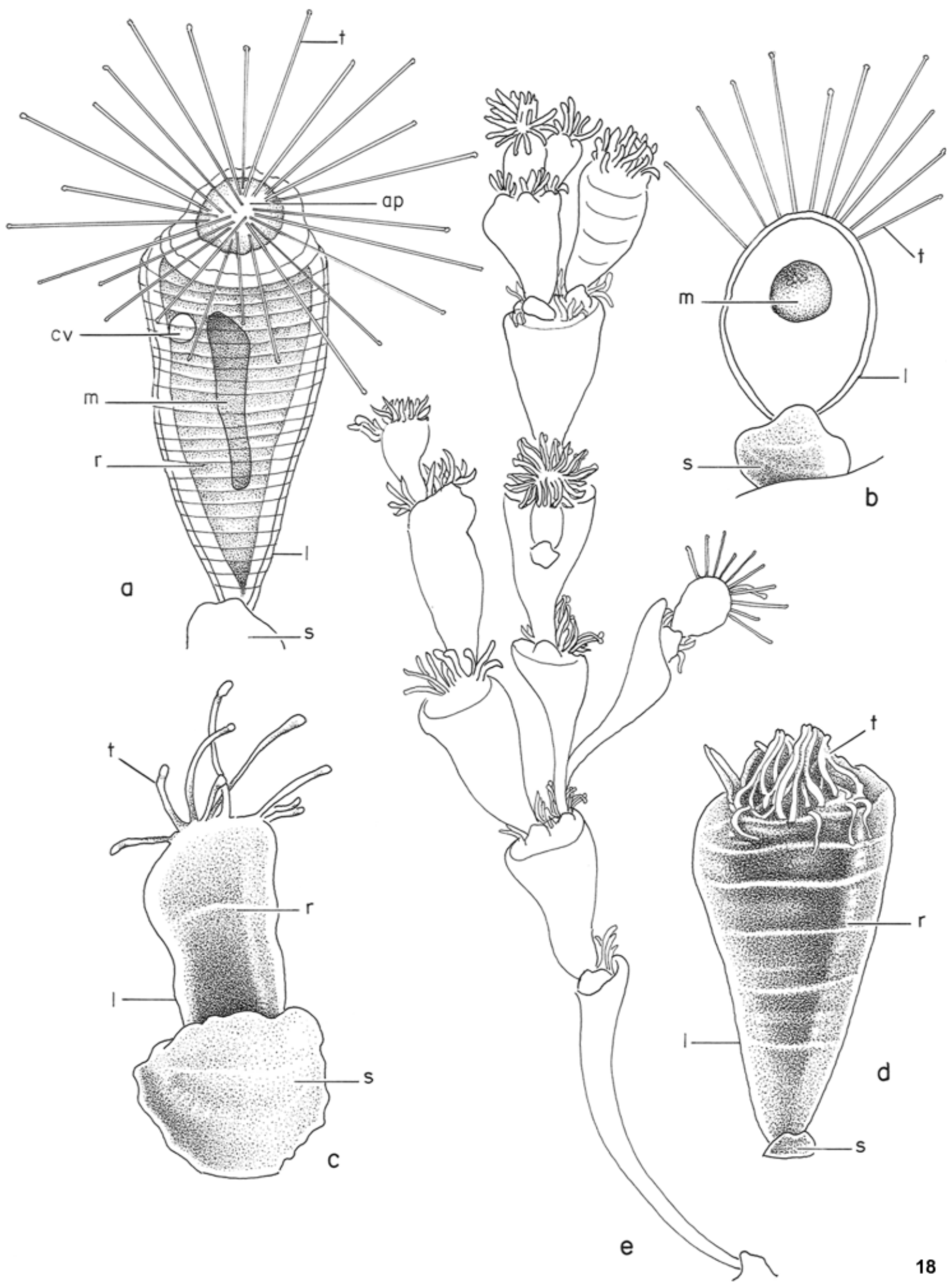

Fig. 18. Schematic drawings of Periacineta mexicana n. sp. attached to aquatic Buenoa spp. a. Detailed morphology of cell. b, c. Younger individuals. d. Lorica surface with ridges. e. Diagram of pseudocolony organization showing the attachment sites. ap, apical part of cell; cv, contractile vacuole; 1 , lorica; $\mathrm{m}$, macronucleus; $r$, ridges; $\mathrm{s}$, stalk; $\mathrm{t}$, tentacles. 


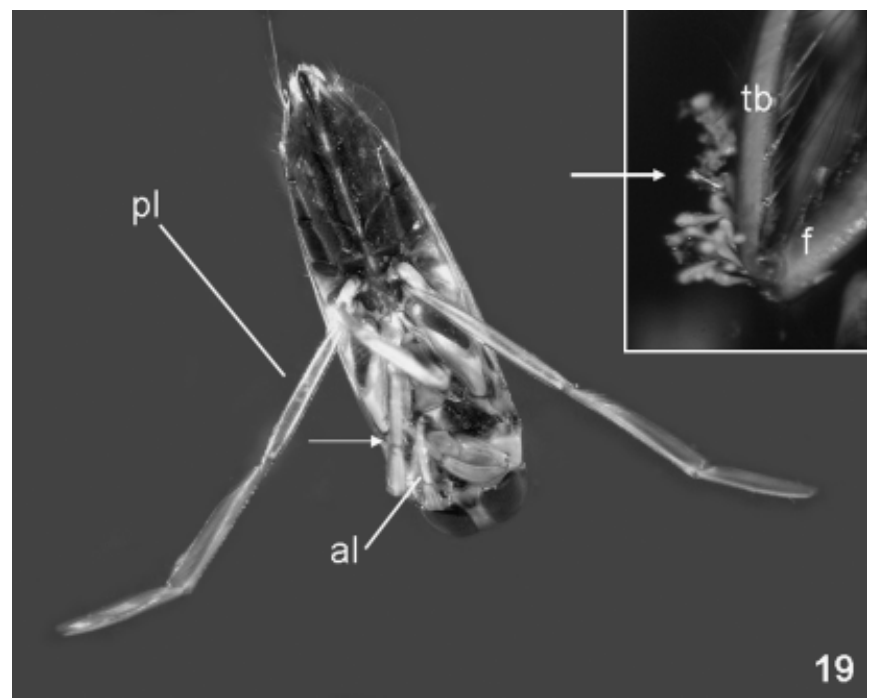

Fig. 19. Individual of Buenoa sp. 2 with Periacineta mexicana $\mathrm{n}$. sp. attached. Black arrow indicates middle pair of legs. Insert shows a pseudocolony of P. mexicana (white arrow) on anterior pair of legs. al, anterior pair of legs; f, femur; pl, posterior pair of legs; tb, tibia.

vacuoles. Freshwater periphytes and epibionts of invertebrates, mainly insects.

Differential diagnosis. Species of Periacineta differ from representatives of the related genera Kormosia Dovgal 2002, Elatodiscophrya Jankowski, 1978, and Peridiscophrya Nozawa, 1938 , by possessing a stalked lorica instead of a thecostyle.

Species composition. Periacineta buckei (Kent, 1882) (type species), P. gyrini Dovgal, 1993, P. heraldica (Jankowski 1981), P. hydrochi (Matthes 1954), P. laccophili (Matthes 1954), $P$. molesta (Matthes 1954), P. notonectae (Claparède et Lachmann, 1859), $P$. paratuberosa (Nie et Ho, 1943), $P$. striata Dovgal, 1993 and P. mexicana n. sp.

\section{Periacineta mexicana $\mathbf{n}$. sp.}

Diagnosis. Loricate suctorian, with elongate, conical body (76-168 $\mu \mathrm{m}$ long by $22-84 \mu \mathrm{m}$ wide), and rounded apical region that protrudes from the lorica for varying distances up to one-half of the length of the entire body. With 10-32 tentacles measuring $25-45 \mu \mathrm{m}$ in length, distributed randomly over the apical region, and not grouped into fascicles and without actinophores. Macro- nucleus in adults, elongate (28-84 $\mu \mathrm{m}$ long, 3-14 $\mu \mathrm{m}$ wide), located centrally and parallel to long axis of body. Lorica conical with transverse ridges, measuring $52-116 \mu \mathrm{m}$ long by $22-84 \mu \mathrm{m}$ wide. Stalk wide and short $(6-18 \mu \mathrm{m}$ long by $6-25 \mu \mathrm{m}$ wide $)$ with a prominent basal disc. Usually occurring as hyperphoretic pseudocolonies consisting of two to six or more individuals. Attached to the first two pairs of legs of B. pallens, Buenoa sp. 1, and Buenoa sp. 2 from Hidalgo, Mexico.

Etymology. The specific name reflects the geographical distribution of the species in Mexico.

Type locality and host. Adult aquatic true bug Buenoa sp. 2 (Hemiptera, Heteroptera, Notonectidae), surfaces of the first two pairs of legs, from type locality, Tecocomulco Lake $\left(19^{\circ} 52^{\prime} 23^{\prime \prime} \mathrm{N}\right.$, $98^{\circ} 23^{\prime} 47^{\prime \prime} \mathrm{W}$ ).

Other localities and hosts. Buenoa sp. 1; Mexico, Hidalgo, Tecocomulco Lake, and B. pallens; Mexico, Hidalgo, pond at Tecomatlán $\left(20^{\circ} 10^{\prime} 60^{\prime \prime} \mathrm{N}, 99^{\circ} 04^{\prime} 00^{\prime \prime} \mathrm{W}\right)$.

Deposition of type material. A hapantotype slide of $P$. mexicana (registry number LP/IHNHgo-001) has been deposited in the slide collection of the Laboratorio de Protozoología, Facultad de Ciencias, Universidad Nacional Autónoma de México. Also 13 paratype slides (registration numbers LP/IHNHgo-002-014) have been deposited in the same collection. Two paratype slides have been deposited at Natural History Museum, London, UK, registration number 2009:8:18:1, and 2009:8:18:2.

\section{ACKNOWLEDGMENTS}

We are grateful to Biól. Armando Zepeda and Biól. Francisco Pasos, Facultad de Medicina, Universidad Nacional Autónoma de México, who kindly processed all SEM material, and for the technical assistance with scanning electron photographs, respectively. From Facultad de Ciencias, UNAM, to M.F.P., Ana I. Bieler is thanked for her help with light photomicrographs (Fig. 14, 16 and 17), and M. A. Aldi de Oyarzábal is thanked for providing the illustrations in Fig. 18. We would like to thank Dr. Paul Tinerella (Illinois Natural History Survey), for his helpful comments of aquatic true bugs identification. Dr. John C. Clamp (Department of Biology, North Carolina Central University) reviewed the manuscript and provided many suggestions. We are very grateful to Dra. Virginia León-Règagnon, M. en C. Jorge López (Instituto de Biología, UNAM), to Dra. Fabiola Ramírez, and P. B. Xóchitl Ventura (Facultad de Ciencias, UNAM), for all technical support for the DNA extraction and PCR amplification of cytochrome oxidase 1 (Buenoa species), and 18S rRNA (P. mexicana), respectively. CONACyT (Consejo Nacional de Ciencia y Tecnología)

Table 4. Comparison of Periacineta mexicana n. sp. with other species of Periacineta.

\begin{tabular}{|c|c|c|c|c|c|c|c|}
\hline Species & $\begin{array}{l}\text { Arrangement } \\
\text { of tentacles }\end{array}$ & Stalk & $\begin{array}{l}\text { Shape } \\
\text { of lorica }\end{array}$ & $\begin{array}{l}\text { Striations } \\
\text { on lorica }\end{array}$ & Macronucleus & $\begin{array}{l}\text { Pseudocolonies } \\
\text { presence }\end{array}$ & Hosts \\
\hline P. buckei & Two fascicles & Short & Trapeziform & None, smooth & $\begin{array}{l}\text { Rounded to } \\
\text { elongated }\end{array}$ & No & $\begin{array}{l}\text { Hemipterans, } \\
\text { coleopterans, mollusks, } \\
\text { aquatic plants }\end{array}$ \\
\hline P. gyrini & Two fascicles & Short & Trapeziform & None, smooth & “ $\Psi$ " shaped & $\mathrm{Yes}^{\mathrm{a}}$ & Gyrinid coleopterans \\
\hline P. heraldica & Two fascicles & Short & Shovel shaped & Striated & “c" shaped & No & Coleopterans \\
\hline P. hydrochi & $\begin{array}{l}\text { Random on apical } \\
\text { region }\end{array}$ & Short & Fan shaped & Striated & “c" shaped & No & Coleopterans \\
\hline P. notonectae & Two fascicles & Short & Conical & None, smooth & Enlarged & No & Corixid hemipterans \\
\hline P. paratuberosa & Two fascicles & Short & Trapeziform & None, smooth & Enlarged & No & Shrimps \\
\hline$P$. striata & Two fascicles & Short & Trapeziform & Striated & Enlarged & No & Coleopterans \\
\hline P. mexicana n.sp. & $\begin{array}{l}\text { Random on apical } \\
\text { region }\end{array}$ & Short & Conical & Striated & Enlarged & Yes & Notonectid hemipterans \\
\hline
\end{tabular}

${ }^{\text {a}}$ Pseudocolony of two individuals; observed only once. 
provided a fellowship to the first author. The Posgrado en Ciencias Biológicas and Secretaría de Intercambio Académico, Facultad de Ciencias, UNAM, supported I. Dovgal for a short stay at UNAM, Mexico.

\section{LITERATURE CITED}

Aescht, E. 2001. Catalogue of the generic names of ciliates (Protozoa, Ciliophora). Denisia, 1:1-350.

Aladro-Lubel, M. A., Mayén-Estrada, R. \& Reyes-Santos, M. 2006. Registro actualizado de ciliados (Agosto 2004). Listados faunísticos de México, XI. Inst. Biol. UNAM.

Aladro-Lubel, M. A., Reyes, M., Olvera, F. \& Robles, M. N. 2007. Ci1iados y otros protozoos. In: Lot, A. (ed.), Guía Ilustrada de la Cantera Oriente: caracterización ambiental e inventario biológico. Coordinación de la Investigación Científica, Sría. Ejecutiv de la Reserva Ecológica del Pedregal de San Angel de Ciudad Universitaria, UNAM, México. p. $97-122$.

Chen, X. R., Song, W. B. \& Hu, X. Z. 2005. Morphology of suctorid ciliates from coastal waters off Qingdao with description of a new genus and a new species (Protozoa, Ciliophora). Acta Zootaxon. Sin., 30:493-500.

Collin, B. 1909. Diagnoses preliminaires d'Acinetiens nouveaux ou mal connus. C. R. Acad. Sci. Paris, 149:1094-1095.

Collin, B. 1912. Etudes monographiques sur les acinetiens. II. Morphologie, physiologie, systematique. Arch. Zool. Exp. Gen., 51:1-457.

Dovgal, I. V. 1988. The knowledge state of tentaculous ciliates (Ciliophora, Suctoria) in Ukrainian SSR// Deposit manuscript in All-Russian Institute of Scientific and Technical Information, 3135-B88, Moscow.

Dovgal, I. V. 1991. Peculiarities of ciliophora Suctoria biocoenotic distribution in water bodies of the right-bank Ukrainian polesje area. Vestn. Zool., 4:54-57 (in Russian with English summary).

Dovgal, I. V. 1996. Keys for identification of tentaculous infusoria (Ciliophora, Suctoria) of the Ukrainian fauna. Vesnt. Zool., 2(Suppl.): 1-42. (in Russian).

Dovgal, I. V. 2002. Evolution, phylogeny and classification of Suctorea Claparède et Lachmann, 1858. Protistology, 2:194-270.

Dovgal, I. V. \& Lozowskiy, V. L. 2008. Limnoricus ponticus sp.n. A new suctorian species (Ciliophora, Suctorea) from the harpacticoid copepode of genus. Tisbe. Vestn. Zool., 42:167-170. (in Russian with English summary).
Fernandez-Leborans, G. \& Tato-Porto, M. L. 2000. A review of the species of protozoan epibionts of crustaceans. II. Suctorian ciliates. Crustaceana, 73:1205-1237.

Fernandez-Leborans, G., Zitzler, K. \& Gabilondo, R. 2006. Epibiont protozoan communities on Caridina lanceolata (Crustacea, Decapoda) from the Malili lakes of Sulawesi (Indonesia). Zool. Anz., 245: 167-191.

Jankowski, A. V. 1981. New species, genera and families of tentacled infusoria (class Suctoria). Proc. Zool. Inst., 107:80-115. (in Russian with English summary).

Jankowski, A. V. 2007. Review of taxa phylum ciliophora Doflein, 1901. In: Alimov, A. F. (ed.), Protista: Handbook on Zoology. Nauka, St. Petersburg. Pt. 2. p. 415-993.

Lunt, D. D., Zhang, D. X., Szymura, J. M. \& Hewitt, G. M. 1996. The insect cytochrome oxidase I gene: evolutionary patterns and conserved primers for phylogenetic studies. Insect Mol. Biol., 5:153-165.

Lynn, D. H. 2008. The Ciliated Protozoa. Characterization, Classification, and Guide to the Literature. 3rd ed. Springer, Dordrecht, Berlin.

Margolis, L., Esch, G. W., Holmes, J. C., Kuris, A. M. \& Schad, G. A. 1982. The use of ecological terms in parasitology (report of an ad hoc committee of the American Society of Parasitologists). J. Parasitol., 68:131-133.

Matthes, D. 1954. Suktorienstudien VII. Discophrya buckei (Kent), eine formenreiche Art der Linguifera-Gruppe. Zool. Anz., 153:242-250.

Matthes, D., Guhl, W. \& Haider, G. 1988. Suctoria und Urceolariidae. Protozoenfauna. Band 7/1. Gustav Fisher Verlag, Stuttgart.

Mayén-Estrada, R. \& Aladro-Lubel, M. A. 1998. Tres especies de suctores (Protozoa: Ciliophora) ectosimbiontes del acocil Cambarellus patzcuarensis. An. Inst. Biol. Univ. Nac. Autón. México, Ser. Zool., 69:1-12.

Puitika, T., Kasahara, Y., Miyoshi, N., Sato, Y. \& Shimano, S. 2007. A taxon-specific oligonucleotide primer set for PCR-based detection of soil ciliate. Microbes Environ., 22:78-81.

Schaefer, H. \& Renner, S. S. 2008. A phylogeny of the oil bee tribe ctenoplectrini (Hymenoptera: Anthophila) based on mitochondrial and nuclear data: evidence of early Eocene divergence and repeated outof-Africa dispersal. Mol. Phylogenet. Evol., 47:799-811.

Truxal, F. S. 1953. A revision of the genus Buenoa (Hemiptera: Notonectidae). Univ. Kansas Sci. Bull., 35:1351-1523.

Received: 09/24/09, 05/28/10; accepted: 06/04/10 